\title{
High-Speed Ice Friction Experiments under Lab Conditions: On the Influence of Speed and Normal Force
}

\author{
Matthias Scherge, ${ }^{1}$ Roman Böttcher, ${ }^{1}$ Mike Richter, ${ }^{2}$ and Udo Gurgel ${ }^{2}$ \\ ${ }^{1}$ Fraunhofer IWM MikroTribologie Centrum, Wöhlerstraße 9, 79108 Freiburg, Germany \\ ${ }^{2}$ Ingenieurbüro Gurgel und Partner, Weinligstraße 11, 04155 Leipzig, Germany \\ Correspondence should be addressed to Matthias Scherge; matthias.scherge@iwm.fraunhofer.de
}

Received 11 October 2012; Accepted 23 October 2012

Academic Editors: L. Bourithis, J. De Vicente, J. Mao, and S. H. Yao

Copyright (c) 2013 Matthias Scherge et al. This is an open access article distributed under the Creative Commons Attribution License, which permits unrestricted use, distribution, and reproduction in any medium, provided the original work is properly cited.

\begin{abstract}
Using a high-speed tribometer, coefficients of friction for bobsled runners were measured over a wide range of loads and speeds. Between $2.8 \mathrm{~m} / \mathrm{s}$ and $28 \mathrm{~m} / \mathrm{s}$ (equal to $10 \mathrm{~km} / \mathrm{h}$ and $100 \mathrm{~km} / \mathrm{h}$ ), the measured coefficients of friction showed a linear decrease with increasing speed. The experiments revealed ultra-low friction coefficients of less than 0.01 after exceeding a sliding speed of about $20 \mathrm{~m} / \mathrm{s}$. At maximum speed of $28 \mathrm{~m} / \mathrm{s}$, the average coefficient of friction was 0.007 . The experiments help to bridge the gap between numerous low-speed friction tests by other groups and tests performed with bobsleds on real tracks. It was shown that the friction data obtained by other groups and our measurements can be approximated by a single master curve. This curve exhibits the largest decrease in friction up to a sliding speed of about $3 \mathrm{~m} / \mathrm{s}$. The further increase in speed generates only a small decrease in friction. In addition, friction decreases with increasing load. The decrease stops when ice wear becomes effective. The load point of constant friction depends on the cross-sectional radius of the runner. The larger the radius is, the higher the load is, before the ice shows signs of fracture. It turned out that besides aerodynamic drag (not considered in this work), ice friction is one of the main speed-limiting factors. In terms of runner geometry, a flat contact of runner and ice ensures the lowest friction. The rocker radius of the runner is of greater importance for a low coefficient of friction than the cross-sectional radius.
\end{abstract}

\section{Introduction}

The precise knowledge of the coefficient of friction $\mu$ is of crucial interest for people designing bobsled tracks, organizers, and technicians. The faster the sleds can travel on the run, the more thrilling the race. But the track must not be too fast: the crew still needs to be able to reach the bottom safely. So engineers have to calculate and simulate exactly how fast a sled can travel on specific sections of the track. The calculations are mainly based on the coefficient of friction between the runners and the ice. The second great impact on speed is aerodynamic drag, which was not investigated here.

Generally, the number of experiments in the past dealing with friction measurements for the system steel versus ice is limited $[1,2]$. Most of the data were obtained with tribometers (e.g., $[3,4])$ or special devices (e.g., $[1,5])$. In the following section, results closest to the system runner/ice will be reviewed. We concentrate on a temperature range between $-2^{\circ} \mathrm{C}$ and $-12^{\circ} \mathrm{C}$.

Evans et al. determined low-friction coefficients by sliding steel on an ice cylinder at a sliding speed $v=1-15 \mathrm{~m} / \mathrm{s}$ at $-11.5^{\circ}$ C. $\mu$ ranged from 0.01 to 0.03 [6]. Similar friction coefficients of about 0.02 were obtained in reciprocating tribometer tests at quasi-static conditions $\left(v=1.5 \times 10^{-7} \mathrm{~m} / \mathrm{s}\right.$ to $7.4 \times 10^{-3} \mathrm{~m} / \mathrm{s}$ ) at rather high pressure of $270 \mathrm{MPa}$ and an ice temperature of $-10^{\circ} \mathrm{C}$ [7]. A $60 \mathrm{~kg}$ sled was constructed by Itagaki et al. and was moved across ice at a speed of $1.5 \mathrm{~m} / \mathrm{s}$. The length of the runners was about $30 \mathrm{~cm}$, thus it can be assumed that the acting pressure was less than $10 \mathrm{MPa}$. For a smooth runner at $T=-5^{\circ} \mathrm{C}$, a coefficient of friction of 0.01 was obtained [8]. Based on ice tribometer experiments at $v$ $=1 \mathrm{~m} / \mathrm{s}$ and $T=-2^{\circ} \mathrm{C}$, Hainzlmaier published coefficients of friction on the order of 0.05 showing a moderate decrease as function of pressure (0.5-6.5 MPa) [9]. Dumm carried out 
tribometer tests at $2 \mathrm{~m} / \mathrm{s}$ and an ice temperature of $-2^{\circ} \mathrm{C}$ using rectangular steel sliders $(4 \mathrm{~mm} \times 8 \mathrm{~mm})$ and obtained coefficients of friction between 0.01 and 0.02 . The pressure range was 1 to $8 \mathrm{MPa}$ [3]. Mills performed experiments with a tribometer as well and measured coefficients of friction between 0.04 and 0.06 for a pressure range between $0.1 \mathrm{MPa}$ and $1 \mathrm{MPa}$ at $v=2 \mathrm{~cm} / \mathrm{s}$ and $T=-2^{\circ} \mathrm{C}$ [4]. Friction decreased to 0.02 when the sliding speed was increased to $3.4 \mathrm{~m} / \mathrm{s}$. In an experiment with a steel ring pressed against the ice, torsion was measured to determine the coefficient of friction. With a pressure of $0.2 \mathrm{MPa}, v=0-3 \mathrm{~m} / \mathrm{s}$ and $T=-10^{\circ} \mathrm{C}$ similar results ( $\mu=0.02-0.04)$ were obtained like Tusima [10].

Data on ultra-low friction coefficients were published by Niven who measured friction between slider and ring ice at $0.9 \mathrm{~m} / \mathrm{s}$ and found $\mu=0.002$ at $T=-2^{\circ} \mathrm{C}[11]$.

De Koning et al. analyzed ice skates [12]. The mean coefficients of friction for straights and curves were 0.0046 and 0.0059 , respectively. Similar results were obtained by Federolf and coworkers [13]. The friction between an ice hockey blade and ice $\left(T=-5.7^{\circ} \mathrm{C}\right.$ and $\left.-4.9^{\circ} \mathrm{C}, v=1.8 \mathrm{~m} / \mathrm{s}\right)$ was in the range of 0.0071 . The acting pressure was not given. Recently, Poirier published friction data for the bobsled obtained on the base of precise speed measurement by radar [14]. Averaging high- and low-speed data, a mean coefficient of friction of 0.0053 was obtained. More data can be found in a review by Itagaki et al. [1].

It is obvious that the measured values vary over a wide range. Up to now, the main problem has been the difficulty of measuring friction over a larger range of high speeds and realistic loads. Thus, the data collected only reflect a small fraction of boundary conditions and, sometimes, seem to be rather far from reality. We therefore introduce a new device for high-speed friction tests at realistic loads. This measuring device allows us to ascertain the precise level of friction between the sled and the ice for bobsled runners with different cross-sectional radii.

\section{Experiments}

2.1. Test Cell and Preparation of Ice. All tests were carried out in a tire test stand. The main piece of the stand is a large drum which is 3.8 meters in diameter and open on one side, situated in a cooled cell, see Figure 1. On the inside of the drum is a layer of ice, on which the model runners slide. A hydraulic cylinder presses the runner to the ice, simulating the weight of the sled and the crew. Whenever the drum rotates, the ice moves out from under the runner, slightly displacing both it and the attached friction force sensor. So instead of remaining at the lowest point, the runner is carried along a little by the rotating drum. Just how far depends on the amount of friction between the runner and the ice. The maximum speed of the test rig is $150 \mathrm{~km} / \mathrm{h}$. In our study we confined the speed range to $100 \mathrm{~km} / \mathrm{h}$ to reduce the noise level in order to detect the expected ultra-low coefficients of friction.

The cooling of the test cell and the drum was started two days before the measurements. The air in the cell was constantly circulated, and the temperature was maintained constant at $-5^{\circ} \mathrm{C}$. One day before the measurement the ice

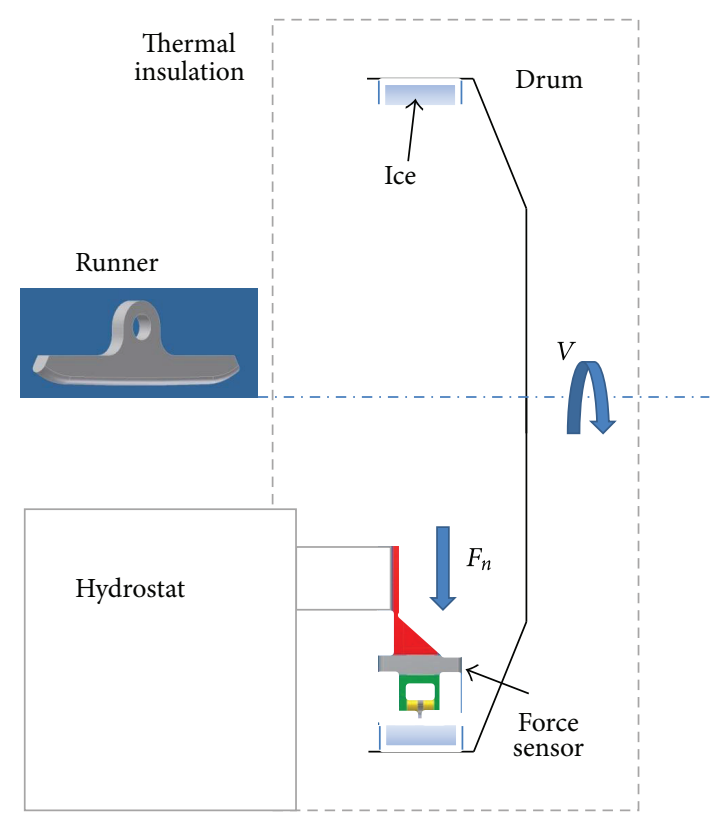

FIGURE 1: Test cell with sensor setup and model runner.

production was started with a flow of distilled water into the rotating drum. The drum turned at $10 \mathrm{~km} / \mathrm{h}$ and moved the water, until a constant thin film of ice was formed. The ice production was ended at an ice thickness of about $3 \mathrm{~cm}$. On the day of the test, the ice surface was smoothed by a twostage process. First, the rough spots were removed with a steel blade. Then the final polishing was performed with a smooth low-profile tire. During this process the tire was rotated at constant speed and the drum rotated as well.

By means of a hydrostat the normal force was exerted to the runner. The normal force range between $100 \mathrm{~N}$ and $500 \mathrm{~N}$ was chosen to simulate a 2-men (man and female) as well as a 4-men bobsleigh. For example, with the selected length of the model runner an applied normal force of about $200 \mathrm{~N}$ corresponded to the load of a 4-men bob sleigh. The force range between $200 \mathrm{~N}$ and $500 \mathrm{~N}$ was selected to simulate curves. Thus, with the used sample geometry of the model runner a pressure range between $20 \mathrm{MPa}$ and $64 \mathrm{MPa}$ was covered.

2.2. Preparation of Runners. The bob runners were made of F.I.B.T. steel 1.4057. Figure 2 shows a drawing of the cross-section and a photograph of the runner after surface finish. For the cross-sectional radius of the runner $4 \mathrm{~mm}$ and $8 \mathrm{~mm}$ were chosen. To realize a flat contact with the drum, each runner was furnished with a rocker radius of $3.8 \mathrm{~m}$. All runners had a length of $15 \mathrm{~cm}$. Both ends were rounded to prevent the runner from scratching the ice. Thus, the length in flat contact with the ice was $10 \mathrm{~cm}$.

The runners were prepared according to the F.I.B.T. regulations following a procedure used in competition. The runners were first polished with sand paper with decreasing grit size followed by a treatment with diamond slurry. Neither machines nor special grinding fluids were applied. 

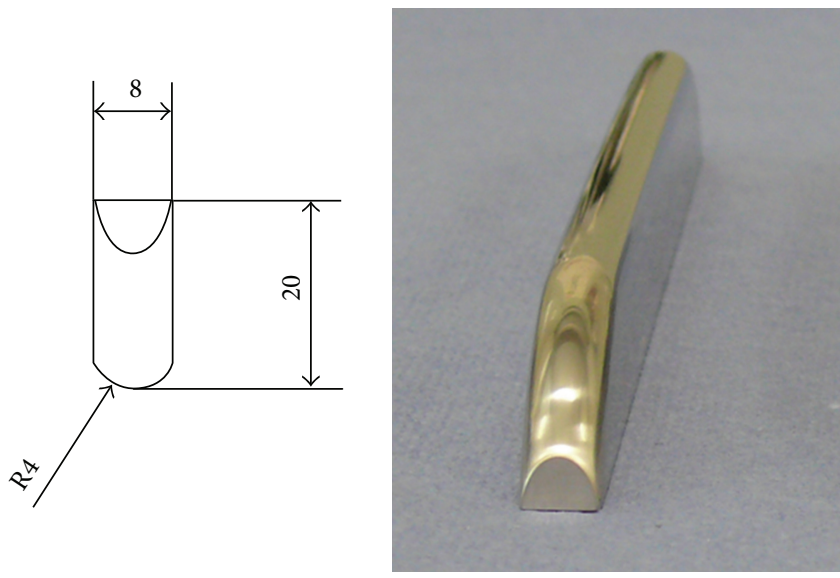

FIGURE 2: Left: schematic of runner. Right: runner after surface finish.

As a result, the surface of the runner showed low roughness as demonstrated in Figure 3. The average roughness was $9 \mathrm{~nm}$ and the peak-to-valley roughness was $118 \mathrm{~nm}$.

2.3. Data Acquisition. All force data were measured using a three-axis sensor (K3D120, ME Messsysteme GmbH, Germany) with a maximum load of $1,000 \mathrm{~N}$. The sensor is very compact with a lateral dimension of $120 \mathrm{~mm} \times 120 \mathrm{~mm}$ and a height of $30 \mathrm{~mm}$. The sensor comes with integrated electronics allowing the separate evaluation of forces in lateral $(x$ and $y$ ) as well as vertical direction $(z)$. The crosstalk from $z$ to $x$ and $y$ at $500 \mathrm{~N}$ is less than $1 \%$. Before friction measurements the sensor was calibrated using designated dead weights. The sensor was then connected to a PC using USB. During all tests both normal $(z)$ and tangential forces $(x)$ were recorded at a sampling rate of $1,000 \mathrm{~Hz}$. To remove noise, the data were low-pass filtered and averaged. To verify the repeatability of the measurements, selected stressing points, that is, a pair of speed and normal force, were tested several times to obtain the error bars. In the diagrams the error bars were always smaller than the size of the symbol.

In order to initiate the measurements, the drum was set in motion and the speed was set. Then, the sensor assembly was slowly lowered until the $z$-sensor displayed the desired normal force.

\section{Results}

3.1. Friction as Function of Speed. The speed dependence was recorded between $2.8 \mathrm{~m} / \mathrm{s}$ and $28 \mathrm{~m} / \mathrm{s}$ (i.e., $10 \mathrm{~km} / \mathrm{h}$ and $100 \mathrm{~km} / \mathrm{h}$ ) with increments of $2.8 \mathrm{~m} / \mathrm{s}$ at a constant load of $500 \mathrm{~N}$, see Figure 4. For both runners a new position on the ice was selected and a linear decrease of the coefficient of friction as function of speed was measured. At a speed of $2.8 \mathrm{~m} / \mathrm{s}$ friction showed values between 0.015 and 0.016 . At highest speed friction ranged between 0.005 and 0.008 . The straight line shows an extrapolation to higher speeds as discussed later. Taking the error bars into account, both curves show similar behavior.

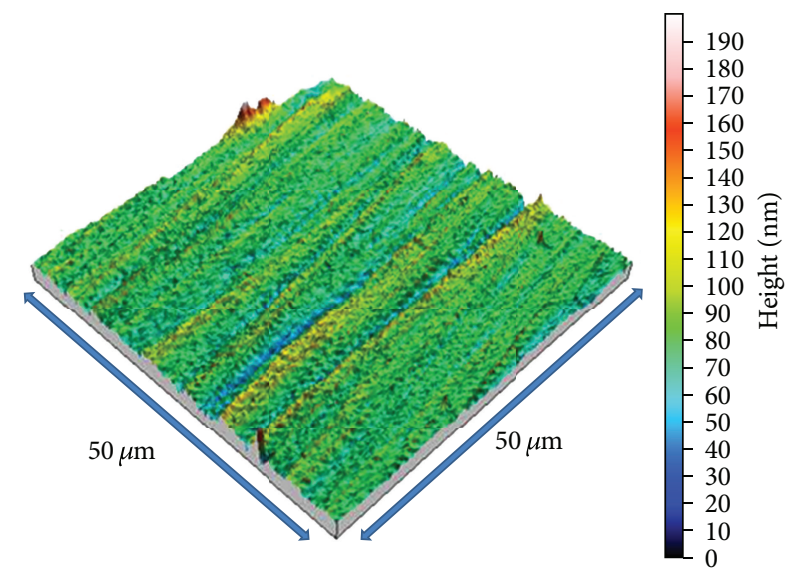

Figure 3: Topography of the runner determined with atomic force microscopy.

3.2. Friction as Function of Load. At a constant speed of $14 \mathrm{~m} / \mathrm{s}(\approx 50 \mathrm{~km} / \mathrm{h})$ the runners were subjected to 5 different loads from $100 \mathrm{~N}$ to $500 \mathrm{~N}$, see Figure 5. For each normal force a new track on the ice was selected. Between $100 \mathrm{~N}$ and $300 \mathrm{~N}$ the coefficients of friction significantly decreased, but remained approximately constant for higher loads. For loads higher than $200 \mathrm{~N}$ the coefficients of friction of the $4 \mathrm{~mm}$ runner were considered constant. For the $8 \mathrm{~mm}$ runner constant friction appeared at $400 \mathrm{~N}$. At higher loads the coefficients of friction run together and showed a value of about 0.011 .

The normal forces indicated by the arrows correspond to the loads of either a 2-men bob (women) of $340 \mathrm{~kg}$ or a 4men bob $(630 \mathrm{~kg})$. That means that a normal force in the labexperiment of about $130 \mathrm{~N}$ is used to simulate the $340 \mathrm{~kg}$ and the lab force of $205 \mathrm{~N}$ corresponds to $630 \mathrm{~kg}$.

3.3. Ice Fracture. Depending on the normal force, wear marks were detected on the ice after the tests. Due to surface irregularities, intermitted wear marks were detected for small 


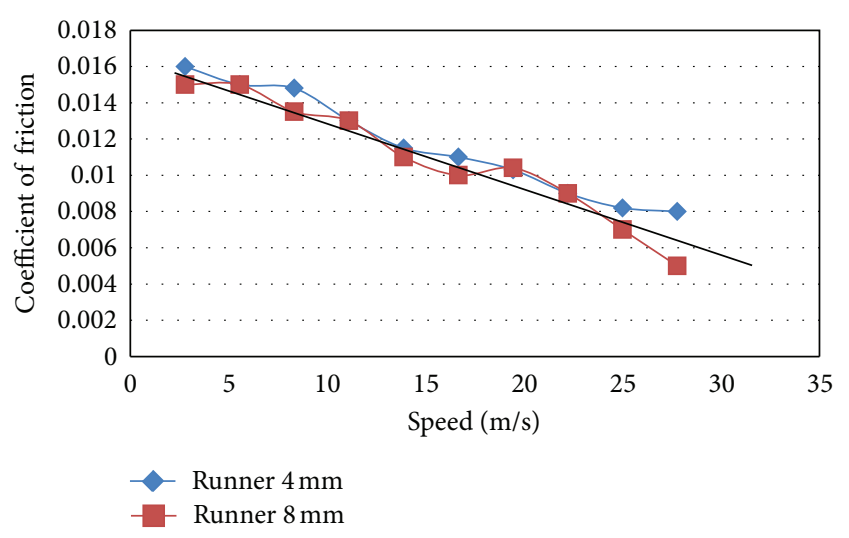

FIgURE 4: Friction as function of speed.

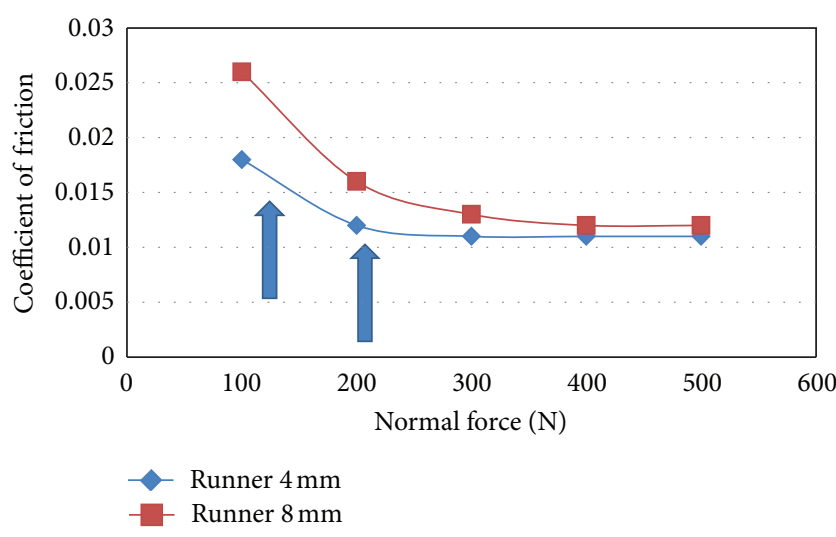

FIGURE 5: Friction as function of load. The left arrow indicates the equivalent normal force executed by a 2 -men bob $(130 \mathrm{~N})$, the right arrow that of a 4-men bob $(200 \mathrm{~N})$.

normal forces, see Figure 6(b). When the normal force increased, continuous wear marks appeared. The highest load of $500 \mathrm{~N}$ caused the widest wear track. In addition, ice debris at the flanks of the runner was detected.

\section{Discussion}

4.1. The Speed Behavior. In the experiments analyzing friction as function of speed the lowest coefficients of friction showed an average value of 0.007 at highest speed. With increasing speed, data scatter increased due to higher mechanical noise. When the linear fit is extrapolated to a speed of $33 \mathrm{~m} / \mathrm{s}(120 \mathrm{~km} / \mathrm{h})$, the coefficient of friction decreases to a value of 0.005 . This value corresponds very well with measurements of Poirier [14].

In Section 1 it was shown that the results of most other groups indicate higher friction coefficients than shown in this paper. Figure 7 shows a summary of literature data combined with results from this work. We use the friction coefficients given in Section 1 and data provided by Itagaki et al. [8].

Our own data represent the average of the friction coefficients obtained for the $4 \mathrm{~mm}$ and the $8 \mathrm{~mm}$ crosssectional radius. The foreign data originate mainly from tests in a pressure range between $1 \mathrm{MPa}$ and $10 \mathrm{MPa}$ and ice temperatures between $-2^{\circ} \mathrm{C}$ and $-12^{\circ} \mathrm{C}$. One experiment was carried out at $270 \mathrm{MPa}$. Except the results of Niven, [11] all coefficients of friction can be approximated by a master curve. With this diagram it can be concluded that-as long as ice fracture is low-the sliding speed is of crucial importance for the magnitude of the coefficient of friction. Moreover, Figure 7 suggests that two distinct friction regimes exist. Up to a speed of about $3 \mathrm{~m} / \mathrm{s}$ the strongest decrease in friction can be observed. For higher speeds the coefficient of friction decreases with constant but significantly smaller slope. It can be speculated that the ability to generate more free water with increasing power of friction saturates at higher sliding speeds. However, to prove this would go beyond the scope of this paper and is reserved for future work.

4.2. The Load Behavior. The acting load presses the runner onto the ice. Both runner and ice are, to a certain degree, elastic media following Hooke's law, $\sigma=\varepsilon E$. The stress $\sigma$ is proportional to strain $\varepsilon$ with Youngs modulus $E$ as proportionality constant. Exceeding the compressive failure stress the ice breaks or shows the first defects, that is, holes or dimples. In Figure 6, we showed that ice fractured after loading and sliding. Hainzlmaier showed that especially in the curves, grooves with a depth of about $180 \mu \mathrm{m}$ in the ice were detected [9]. According to literature the compressive failure stress of ice ranges between $1 \mathrm{MPa}$ and about $40 \mathrm{MPa}$, depending on ice temperature and strain rate $[15,16]$. A review of literature data showed a compressive failure stress of about $25 \mathrm{MPa}$ at a strain rate of $10^{3} \mathrm{~s}^{-1}$ [17]. At a strain rate of $10^{4} \mathrm{~s}^{-1}$-achieved with our setup at $28 \mathrm{~m} / \mathrm{s}$-ice ( $T$ $=-10^{\circ} \mathrm{C}$ ) can develop a compressive failure stress of more than $40 \mathrm{MPa}$ [16]. The impact of compressive failure stress on friction can be seen in Figure 5. At a certain normal force, that is, $>200 \mathrm{~N}$ for the $4 \mathrm{~mm}$ runner and $>400 \mathrm{~N}$ for the $8 \mathrm{~mm}$ runner, the coefficients of friction became constant. The question is how the compressive failure stress is related to the friction coefficient. To answer this question, Hertzian contact mechanics [18] was applied to calculate the acting pressure between runner and ice for elastic boundary conditions, see Figure 8 . The inset of the figure shows the reduced mechanical setup. We treat the section of the model runner that is in contact with the ice as cylinder with the length $l=10 \mathrm{~cm}$. Supplying the values for acting normal force $F_{n}$ and crosssectional radius $(4 \mathrm{~mm}$ and $8 \mathrm{~mm}$ ) to (1), the maximum pressure $p_{\max }$ and the contact width $b$ were calculated:

$$
p_{\max }=\sqrt{\frac{F_{n} E}{2 \pi r l\left(1-v^{2}\right)}}
$$

with

$$
\begin{gathered}
r=\frac{r_{1} r_{2}}{r_{1}+r_{2}}, \\
E=2 \frac{E_{1} E_{2}}{E_{1}+E_{2}} .
\end{gathered}
$$

$E_{1}$ and $E_{2}$ are Youngs moduli of steel $(210 \mathrm{GPa})$ and ice $9.31 \mathrm{GPa}, r_{1}$ is the cross-sectional radius of the cylinder, and 


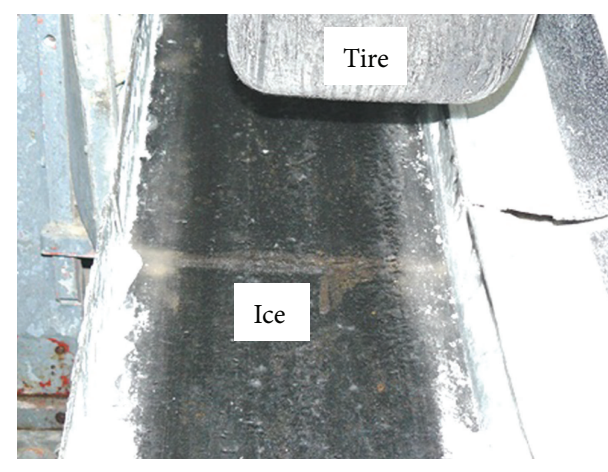

(a)

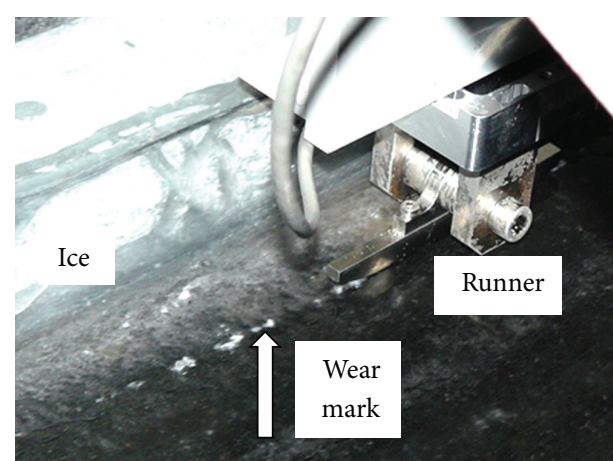

(b)

FIGURE 6: (a) Ice after preparation with the low-profile tire. (b) Wear marks on the ice after contact with the runner.

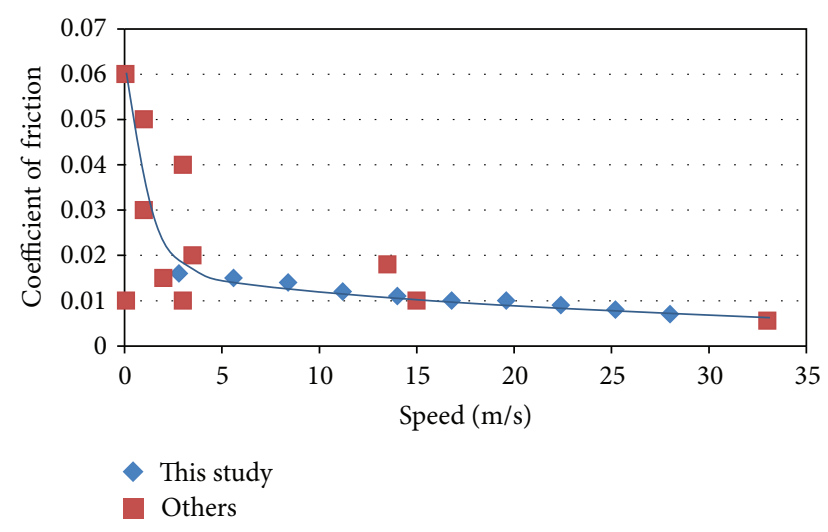

Figure 7: Friction versus speed with results of this work and of others.

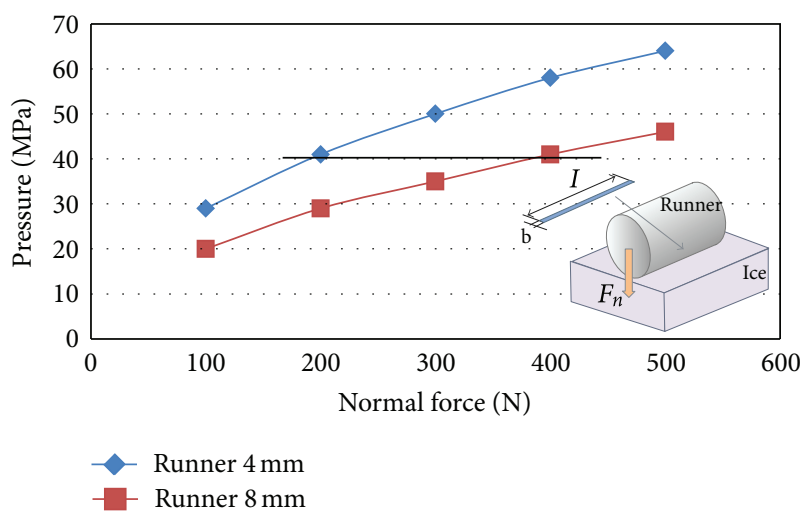

FIGURE 8: Hertzian contact pressure as function of load. The inset shows the mechanical setup of cylinder (model runner) versus flat (ice).

$r_{2}=\infty$, since the ice was treated as flat surface. $v$ is the Poisson ratio of 0.33 [19]. With the given parameters, the contact width ranges between $20 \mu \mathrm{m}$ and $60 \mu \mathrm{m}$.

The compressive failure stress of $40 \mathrm{MPa}$ was attained at $200 \mathrm{~N}$ for the $4 \mathrm{~mm}$ runner and for the $8 \mathrm{~mm}$ runner at $400 \mathrm{~N}$. This corresponds well with the findings shown in Figure 5. For higher normal forces Figure 8 loses its meaning, since ice fractures and structural defects of the ice are the consequences [20]. Due to cracked ice the wear track becomes wider, thus, the real area of contact $A$ becomes larger.

Increasing normal force as well as increasing speed decreases the friction force $F_{f}$ by lowering the shear stress $\tau$ due to generation of a thin water film [21]

$$
F_{f}=\tau A
$$

However, with increasing contact area both influences seem to equilibrate and friction becomes constant for normal forces higher than $200 \mathrm{~N}$ (4 mm runner) and higher than $400 \mathrm{~N}$ (8 mm runner). A detailed analysis of $\tau$ using a microtribometer will be subject of a future study.

While the coefficient of friction at the load point of a 4-men bob is located in the constant section of the friction curve of Figure 5, the friction coefficients in the load range of the 2-men bob significantly changes with load. This means that for the 2-men bob the addition of ballast (if possible) has a strong impact on the coefficient of friction, thus the speed of the bob. For the 4-men bob this influence can be neglected.

\section{Conclusions}

With the help of a high-speed tribometer coefficients of friction were determined for the contact of bobsled runner versus ice. The results can be concluded as follows.

(i) Ultra-low coefficients of friction can be obtained when the sliding speed is higher than $3 \mathrm{~m} / \mathrm{s}$. At $v>$ $20 \mathrm{~m} / \mathrm{s}$ the friction coefficients become lower than 0.01 .

(ii) The magnitude of friction depends on the contact pressure. For pressures higher than $40 \mathrm{MPa}$ ice fracture prohibits further decrease of friction. Despite ice fracture friction is extremely low.

(iii) The contact pressure can be increased by additional weights. This measure is more effective for the 2men bobs, since the friction curve decreases with increasing load. Friction starts to become constant at the load of a 4-men bob. 
(iv) Since the acting pressure, especially in curves, is almost always higher than the compressive failure stress of the ice, the rocker radius of the runner should be carefully adapted to the curve radii of the track in order to realize an adjusted contact. Punctual contacts should be omitted.

(v) Measurements and calculation showed that the rocker radius is of greater importance for low friction than the cross-sectional radius. This conclusion is supported by the fact that in this study a flat contact was simulated. The rocker radius was equal to the inner radius of the drum. High loads induce ice fracture. The reduction of the rocker radius would lead to punctual contacts with increased pressure. Thus, ice friction would start at lower normal forces.

\section{References}

[1] K. Itagaki, N. P. Huber, and G. E. Lemieux, Dynamic Friction of a Metal Runner on Ice, CRREL Report, 1989.

[2] A. Penny, E. Lozowski, T. Forest, C. Fong, S. Maw, and P. Montgomery, "Speedskate ice friction: review and numerical model-FAST 1. 0," in Physics and Chemistry of Ice, F. Wilhelms and W. A. Kuhs, Eds., pp. 495-504, 2007.

[3] M. Dumm, C. Hainzlmaier, S. Boerboom, and E. Wintermantel, "The effect of pressure on friction of steel and ice and implementation to bobsleigh runners," in The Engineering of Sport 6, vol. 3, pp. 103-106, 2006.

[4] A. Mills, "The coefficient of friction, particularly of ice," Physics Education, vol. 43, no. 4, pp. 392-395, 2008.

[5] T. Kobayashi, "Studies of the properties of ice in speed-skating rinks," Ashrae Journal, vol. 15, no. 1, pp. 51-56, 1973.

[6] D. C. B. Evans, J. F. Nye, and K. J. Cheeseman, "The kinetic friction of ice," Proceedings of the Royal Society of London, vol. 347, no. 1651, pp. 493-512, 1976.

[7] K. Tusima, "Friction of a steel ball on a single crystal of ice," Journal of GIaciology, vol. 19, no. 81, pp. 225-235, 1977.

[8] K. Itagaki, G. E. Lemieux, and N. P. Huber, "Preliminary study of friction between ice and sled runners," Journal De Physique, vol. 48, no. 1, pp. 297-301, 1987.

[9] C. Hainzlmaier, A New tribologically optimmized bobsleigh runner [Dissertation], TU München, 2006.

[10] L. Fransson, A. Patil, and H. Andren, "Experimental investigation of friction coefficient of laboratory ice," in Proceedings of the 21st International Conference on Port and Ocean Engineering under Arctic Conditions, Montréal, Canada, 2011.

[11] C. D. Niven, "On the friction of heated sleigh runners on ice under high loading," Canadian Journal of Technology, vol. 34, pp. 227-231, 1956.

[12] J. J. De Koning, G. De Groot, and G. J. V. I. Schenau, "Ice friction during speed skating," Journal of Biomechanics, vol. 25, no. 6, pp. 565-571, 1992.

[13] P. A. Federolf, R. Mills, and B. Nigg, "Ice friction of flared ice hockey skate blades," Journal of Sports Sciences, vol. 26, no. 11, pp. 1201-1208, 2008.

[14] L. Poirier, Ice friction in the sport of bobsleigh [Ph.D. thesis], University of Calgary, 2011.

[15] E. M. Schulson, "Brittle failure of ice," Engineering Fracture Mechanics, vol. 68, no. 17-18, pp. 1839-1887, 2001.
[16] M. Shazly, V. Prakash, and B. A. Lerch, "High strain-rate behavior of ice under uniaxial compression," International Journal of Solids and Structures, vol. 46, no. 6, pp. 1499-1515, 2009.

[17] K. S. Carney, D. J. Benson, P. DuBois, and R. Lee, "A phenomenological high strain rate model with failure for ice," International Journal of Solids and Structures, vol. 43, no. 25-26, pp. 7820-7839, 2006.

[18] H. Hertz, "Über die Berührung fester elastischer Körper," Journal Für Die Reine Und Angewandte Mathematik, vol. 92, pp. 156-171, 1881.

[19] J. J. Petrovic, "Mechanical properties of ice and snow," Journal of Materials Science, vol. 38, no. 1, pp. 1-6, 2003.

[20] E. M. Schulson, “The brittle compressive fracture of ice," Acta Metallurgica Et Materialia, vol. 38, no. 10, pp. 1963-1976, 1990.

[21] F. P. Bowden and T. P. Hughes, "The mechanics of sliding on ice and snow," Proceedings of the Royal Society London A, vol. 172, pp. 280-298, 1939. 

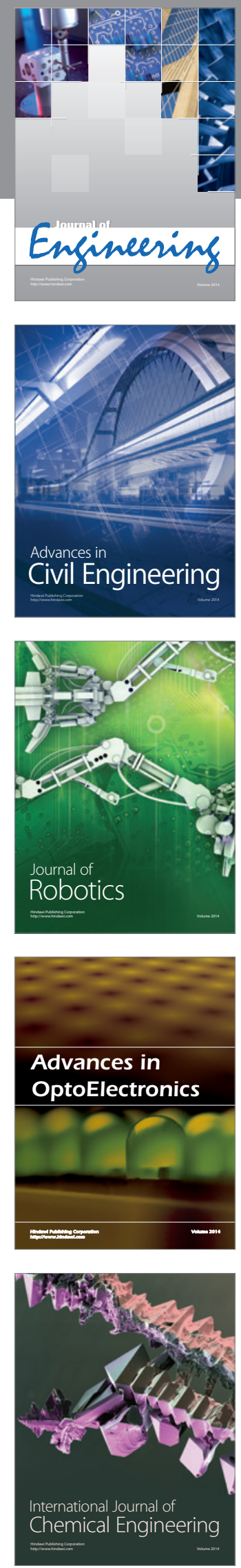

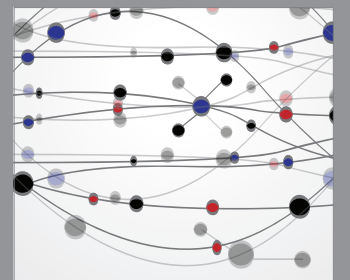

The Scientific World Journal
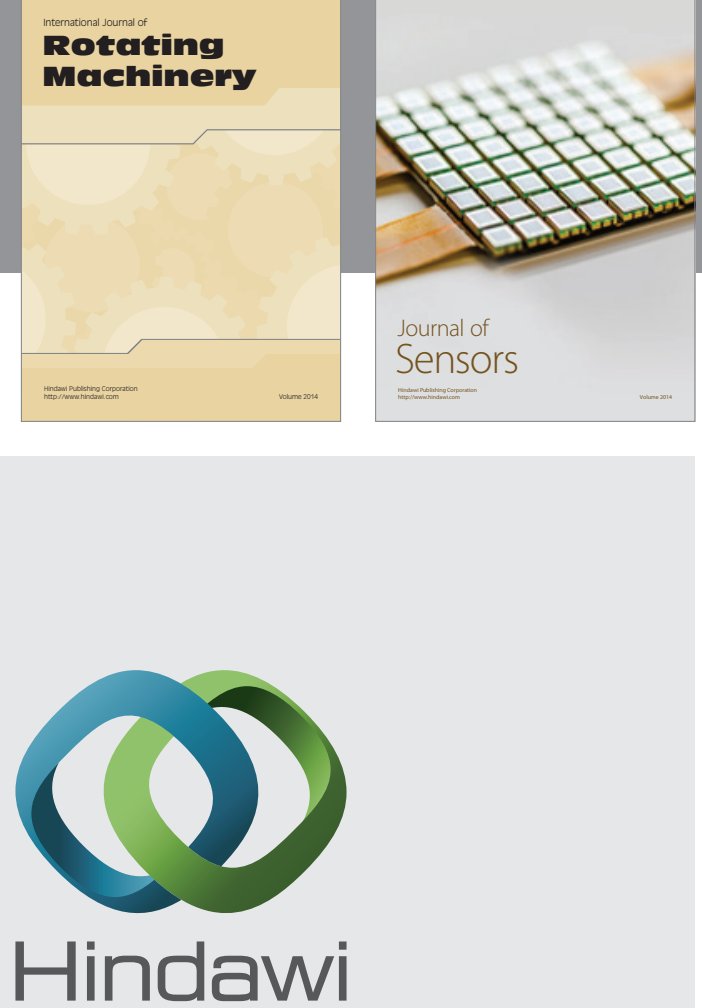

Submit your manuscripts at http://www.hindawi.com
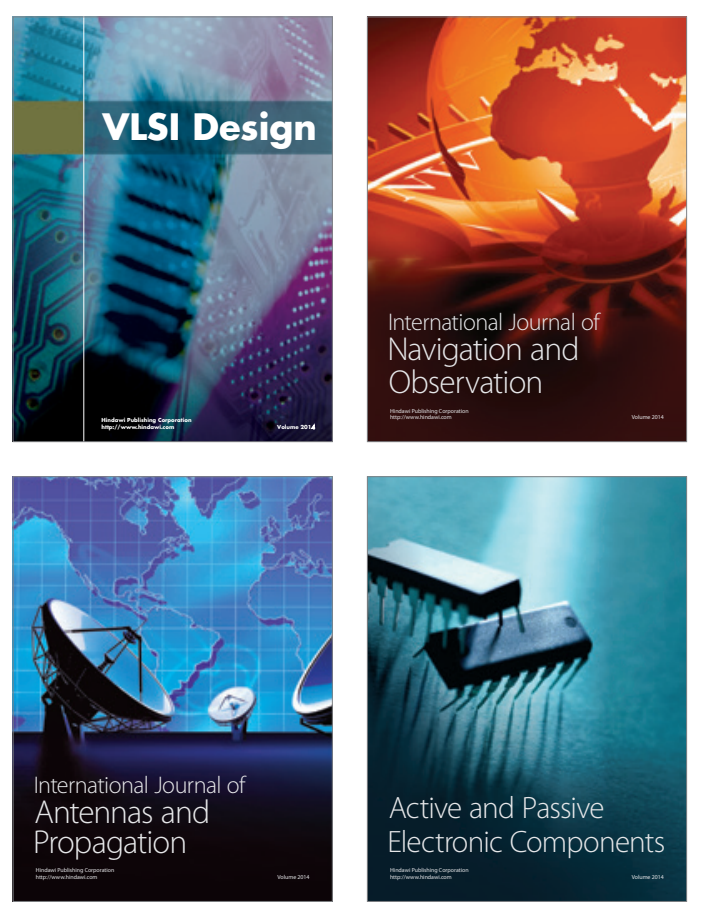
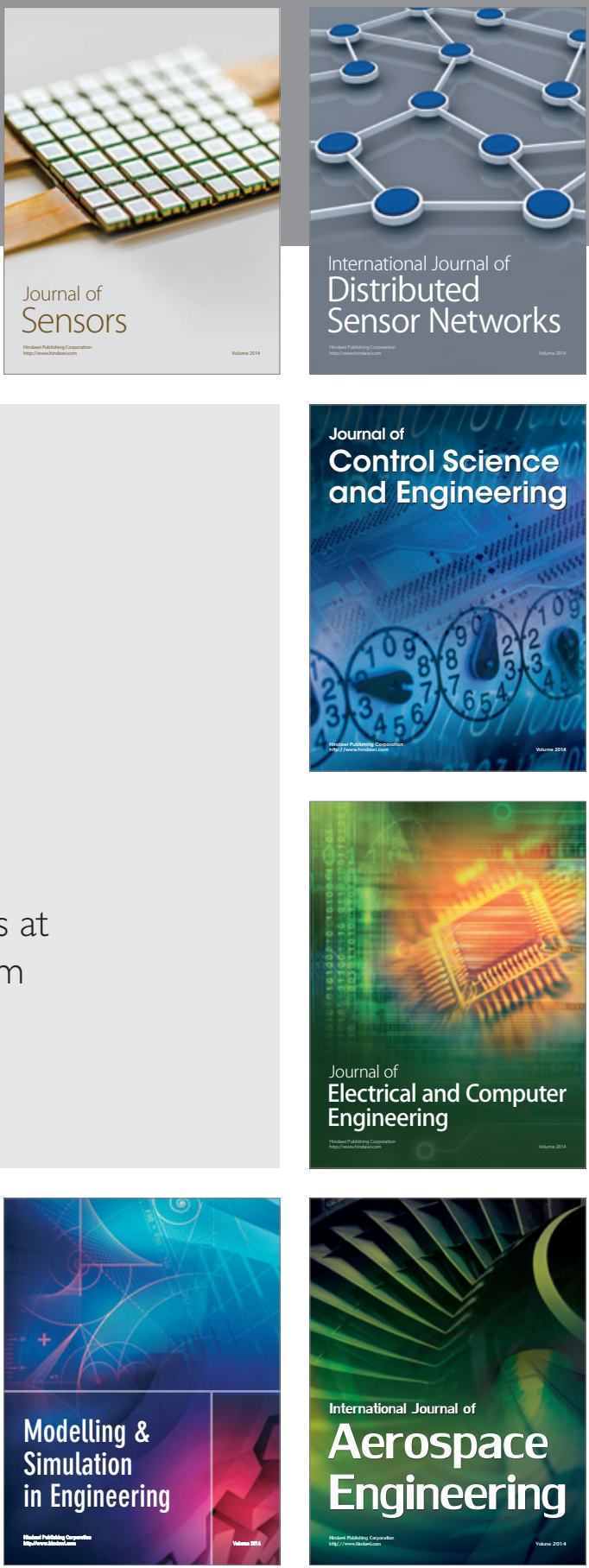

Journal of

Control Science

and Engineering
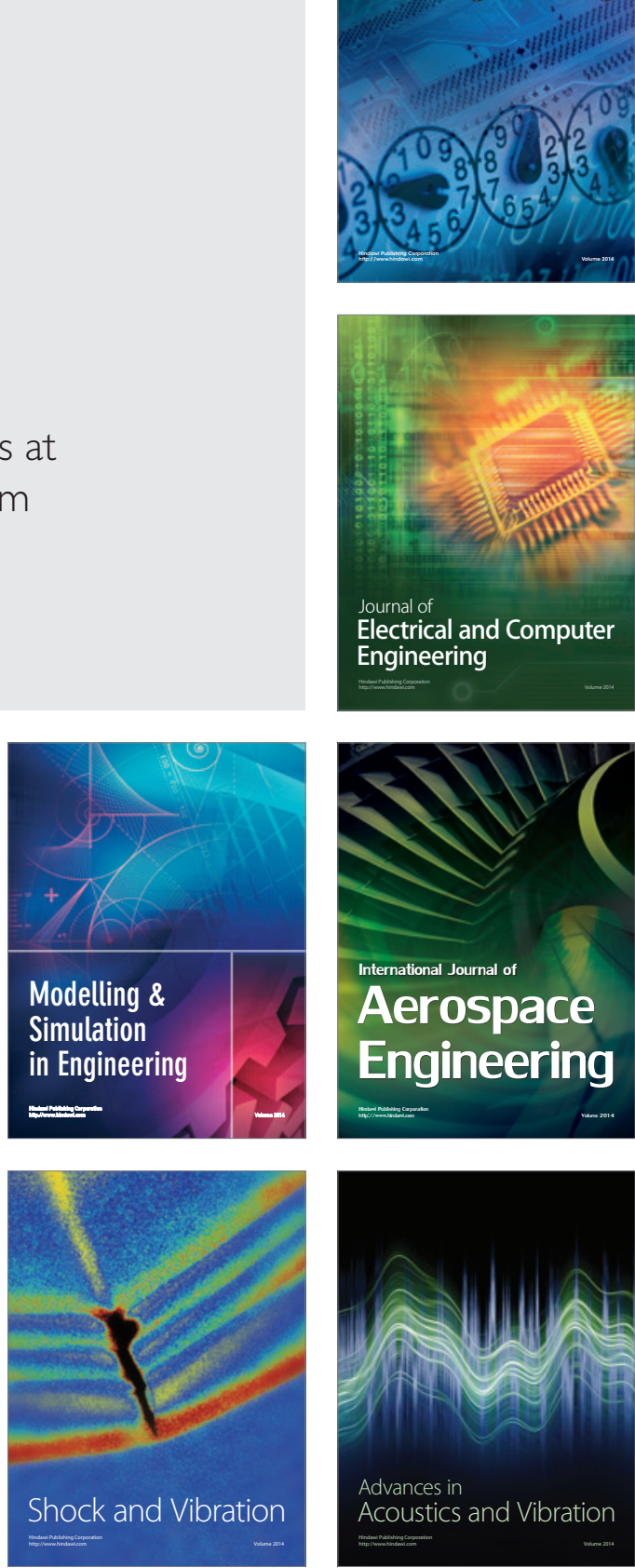